\title{
Regimes de trabalho, controles econômico- financeiros e arenas da copa: o desenvolvimento em discussão
}

\section{Anderson Catapan \\ catapan@utfpr.edu.br \\ Universidade Tecnológica Federal do \\ Paraná, Curitiba, Paraná, Brasil. \\ Antonio Gonçalves de Oliveira agoliveira@utfpr.edu.br \\ Universidade Tecnológica Federal do Paraná, Curitiba, Paraná, Brasil.}

\section{EDITORIAL}

Este editorial apresenta os artigos do primeiro número do sétimo volume da Revista Brasileira de Planejamento e Desenvolvimento (RBPD). Este número trouxe contribuições para o planejamento e desenvolvimento, assim como em números anteriores e já de praxe deste periódico, de professores do Brasil e de diversos outros países.

O primeiro artigo de Almeida e Lima (2018) analisa a segurança e saúde no trabalho no regime CLT e no regime estatutário. Depois, Gonçalves et al. (2018) fazem um estudo sobre modelagem marítima no caso do arquipélago da Madeira, em Portugal.

Em seguida, Anacleto e Bornacin (2018) analisam o perfil assim como o comportamento de consumidores de bromélias. No quarto artigo, Padilha, Araújo e Souza (2018) abordam a influência das incertezas nas contratações públicas por intermédio do pregão eletrônico.

O próximo artigo, assinado por Fontoura e Deponti (2018) apresenta uma discussão sobre a importância das TICS e dos controles econômicos e financeiros na visão dos agricultores familiares do Vale do Caí-RS. No sexto artigo de Leão et al. (2018) discutem sobre as arenas da copa como estética pósdesenvolvimentista.

Depois, Santos e Rocha (2018) realizam uma discussão com a tentativa de busca de uma gênese para a defesa civil no Brasil. No último texto na seção de artigos originais, Miranda et al. (2018) fazem uma abordagem sobre os estudos hidráulicos e a sua influência no planejamento urbano e regional no contexto de Portugal.

Ainda, este número traz a primeira resenha da RBPD, assinada por Rita de Cássia Gonçalo, e intitulada de: "Metrópoles latino-americanas: experiências e desafios".

Aproveitamos para agradecer a contribuição de todos os autores e avaliadores de nossa revista. Apresentados os artigos deste número, desejamos uma ótima e proveitosa leitura a todos!!! 